[Agr. Biol. Chem., Vol. 34, No. 2, p. 227 233, 1970]

\title{
The Formation of Aldehydes from Amino Acids by Tea Leaves Extracts
}

\author{
By Ryoyasu SAIJō and Tadakazu TAKeo \\ Tea Research Station, Ministry of Agriculture and Forestry, \\ Kanaya, Shizuoka \\ Received July 3, 1969
}

\begin{abstract}
In the reaction system containing amino acid, tea leaves extract and (-)-epicatechin, some amino acids such as glycine, alanine, valine, leucine, isoleucine, methionine and phenylalanine produced formaldehyde, acetaldehyde, isobutyraldehyde, isovaleraldehyde, 2methylbutanal, methional and phenylacetaldehyde, respectively. The production of these aldehydes was regarded to proceed as Strecker degradation. On the production of phenylacetaldehyde it was revealed in the tea leaves extract-phenol-phenylalanine system that: 1) di-phenol was the most effective co-factor in comparison with mono- and tri-phenols; 2) the optimum concentration of (-)-epicatechin was $5 \times 10^{-4} \mathrm{M}$ and the production was depressed at the concentration more than $\left.5 \times 10^{-4} \mathrm{M} ; 3\right)$ the production decreased by diluting tea leaves extract.
\end{abstract}

Several carbonyl compounds of black tea were supposed to be formed from amino acids by Strecker degradation. ${ }^{1 \sim 3 \prime}$ In the previous paper we reported that phenylalanine degraded into phenylacetaldehyde and carbon dioxide in the process of tea fermentation. The objectives of the present study were to reveal the production of the corresponding aldehydes from various amino acids by tea leaves extract and to study the formation mechanism of aldehydes using phenylalanine as the substrate.

\section{MATERIALS AND METHODS}

Preparation of tea leaves extract. The young tea leaves, field-grown in autumn of variety Benifuji were homogenated by the method reported previously $y^{4}$ and

1) M. A. Bokuchava and V. R. Popov, Doklady Akad. Nauk S.S.S.R., 99, 145 (1954) [C.A., 49, 3439c (1955)].

2) T. Nakabayashi, Nippon Nogeikagaku Kaishi, 32, 941 (1958).

3) R. Saijō and T. Takeo, Agr. Biol. Chem., 34, $222(1970)$.

4) T. Takeo, ibid., 29, 558 (1965). stored in $\left(\mathrm{NH}_{4}\right)_{2} \mathrm{SO}_{4}$ solution, $42 \mathrm{~g}\left(\mathrm{NH}_{4}\right)_{2} \mathrm{SO}_{4}$ per 100 $\mathrm{ml}$ buffer solution, until winter when it was used. The homogenate was dialysed against $0.2 \mathrm{M}$ McIlvaine buffer ( $\mathrm{pH} 7.0$ ), containing $1 \%$ sodium ascorbate, for $48 \mathrm{hr}$ and filtered. The resultant residue was suspended in $0.2 \mathrm{M}$ Mcllvaine buffer ( $\mathrm{pH} 7.0$ ), containing 5 $\%$ Tween-804 and $1 \%$ sodium ascorbate, extracted for $2 \mathrm{hr}$, and then centrifuged for $5 \mathrm{~min}$ at $12,000 \times \mathrm{g}$. The supernatant was applied to Sephadex G-25 column, $2 \times 15 \mathrm{~cm}$. Using $0.2 \mathrm{M} \mathrm{Mcllvaine} \mathrm{buffer} \mathrm{as} \mathrm{the} \mathrm{eluting}$ buffer, fractions containing protein were collected. The protein fractions were precipitated with $\left(\mathrm{NH}_{4}\right)_{2} \mathrm{SO}_{4}$, $21 \mathrm{~g}$ per $100 \mathrm{ml}$ buffer solution, collected by centrifugation for $15 \mathrm{~min}$ at $10,000 \times g$ and the supernatant was again applied to Sephadex G-25 column. The resultant protein fractions, having activity of polyphenol oxidase, were used as tea leaves extract to the following experiments.

Incubation methods. Incubation was carried out in $50 \mathrm{ml}$ flask containing 6 to $9 \mathrm{ml}$ of phosphate buffer solution for $2 \mathrm{hr}$ at $25^{\circ} \mathrm{C}$ unless otherwise stated. Phosphate buffer solution ( $\mathrm{pH}$ 7.0) was prepared from M/15 $\quad \mathrm{KH}_{2} \mathrm{PO}_{4}$ and $\mathrm{M} / 15 \mathrm{NaHPO}_{4}$. The composition of the reaction mixture was shown in each table and figure. 
Quantitative analysis of phenylacetaldehyde by gas chromatography. Volatile compounds were extracted from the reaction mixture with diethylether. The extract was dehydrated with $\mathrm{Na}_{2} \mathrm{SO}_{4}$ and concentrated. All of the resultant concentrate was applied to gas chromatography, the condition of which was the same as described previously3) except $1 / 30$ sensitivity of flame ionization detector. The retention time of phenylacetaldehyde was $29.5 \mathrm{~min} *$. From the peak area its quantity was calculated by the use of the caliburation curve shown in Fig. 1.

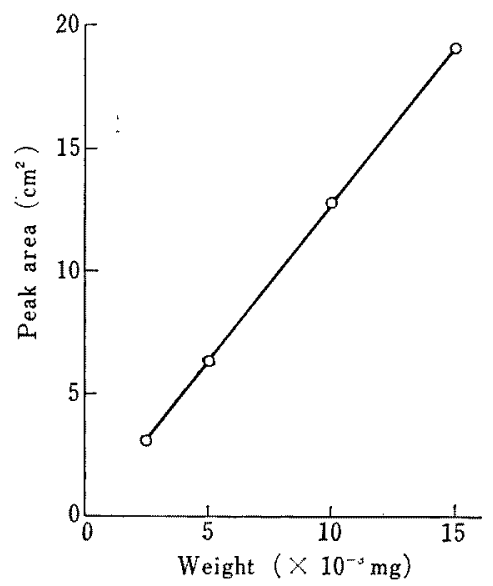

FIG. 1. Calibration Curves of Phenylacetaldehyde.

Column: Carbowax 6000, Temp.: $150^{\circ} \mathrm{C}, \mathrm{He}$ flow rate: $30 \mathrm{ml} / \mathrm{min}$. Detector: FID, Sens.: $1 / 30$, Chart speed: $1 \mathrm{~cm} / \mathrm{min}$.

Measurement of total carbonyl contents by titration. Total carbonyl compounds were extracted with diethylether from the reaction mixture, and then reacted with $5 \mathrm{ml}$ of $1 \mathrm{~N} \mathrm{NaHSO}_{3}$ for $70 \mathrm{~min}$ at $5^{\circ} \mathrm{C}$ to form carbonyl compounds- $\mathrm{NaHSO}_{3}$ complex. After residual $\mathrm{NaHSO}_{3}$ was titrated with $1 \mathrm{~N} \mathrm{I}_{2}$ (indicator, $1 \%$ starch solution), excess $\mathrm{I}_{2}$ was also titrated with $0.1 \mathrm{~N} \mathrm{NaHSO}$ and precisely with $\mathrm{N} / 100 \mathrm{I}_{2}$. The carbonyl compounds$\mathrm{NaHSO}_{3}$ complex was decomposed by adding $\mathrm{NaHCO}_{3}$ and stand for $10 \mathrm{~min}$ at room temperature. Resultant $\mathrm{SO}_{2}$ liberated was titrated with $\mathrm{N} / 100 \mathrm{I}_{2}$. The titration value was proportional to original carbonyl compounds.

* As the retention time of benzaldehyde was 18.6 min, these aldehydes could be separated clearly.
2,4-Dinitrophenylhydrazones and thin-layer chromatography of volatile carbonyl compounds. The preparation of 2,4-dinitrophenylhydrazones (2,4-DNPH) of carbonyl compounds and thin-layer chromatography were done according to the methods described previously. ${ }^{31}$ After the developement of thin layer chromatography main 2,4-DNPH was scraped off with a spatula, eluted by acetone and recrystallized from ethanol-water.

Spectrometry. Absorption spectra were determined in water solution by a Beckman DB spectrophotometer.

Chemicals. (+)-Catechin, (-)-epicatechin, (-)epigallocatechin, (-)-epigallocatechin gallate were supplied by Dr. M. Nakagawa.51 Those were isolated from tea and other plants in pure state. Other chemicals were the highest grade commercially available.

\section{RESULTS}

Reaction systems in which phenylacetaldehyde was produced from phenylalanine by tea leaves extract

As shown in Table I, phenylacetaldehyde was produced, when (-)-epicatechin was added to the reaction mixture of phenylalanine and tea leaves extract (No. 2). Since hydrogen peroxide and $\mathrm{Mn}^{2+}$ showed the stimulating effect on the production of phenylacetaldehyde (No. 4, 5), it was revealed as shown in No. 6, 7 that these factors activated the peroxidase system in tea leaves extract. Reaction systems of No. 9, 10 showed that phenylacetaldehyde was formed by the reaction between phenylalanine and $o$-quinone. Therefore, the mechanism of phenylacetaldehyde production was considered to be the reaction between phenylalanine and $o$-quinone derived from (-)-epicatechin by polyphenol oxidase or peroxidase. When pyridoxal phosphate, $\mathrm{Mn}^{2+}$ and mono-phenol were added in tea leaves extract and phenylalanine (No. 12), benzaldehyde was produced

5) M. Nakagawa and H. Torii, Agr. Biol. Chem, 28,160 (1964).

6) M. H. Yu, D. K. Salumkhe and L. E. Olson, Plant $\mathcal{S}^{2}$ Cell Thysiol., 9, 633 (1968). 
Table I. The Production of Phenylacetaldehyde in Various REACTION SYSTEMS

\begin{tabular}{|c|c|c|}
\hline \multicolumn{2}{|r|}{ Reaction system } & \multirow{2}{*}{ Phenylacetaldehyde $\times 10^{-2} \mu$ mole } \\
\hline No. & Composition & \\
\hline 1 & Phe + TLE & 0 \\
\hline 2 & $\mathrm{Phe}+\mathrm{TLE}+(-) \mathrm{EC}$ & 1.9 \\
\hline 3 & $\mathrm{Phe}+\mathrm{TLE}+\mathrm{H}_{2} \mathrm{O}_{2}$ & 0 \\
\hline 4 & $\mathrm{Phe}+\mathrm{TLE}+(-) \mathrm{EC}+\mathrm{H}_{2} \mathrm{O}_{2}$ & 3.3 \\
\hline 5 & $\mathrm{Phe}+\mathrm{TLE}+(-) \mathrm{EC}+\mathrm{Mn}^{2+}$ & 2.1 \\
\hline 6 & $\mathrm{Phe}+\mathrm{HRP}+(-) \mathrm{EC}+\mathrm{H}_{2} \mathrm{O}_{2}$ & 8.3 \\
\hline 7 & $\mathrm{Phe}+\mathrm{HRP}+(-) \mathrm{EC}+\mathrm{Mn}^{2+}$ & 4.5 \\
\hline 8 & Phe + TLE $\left(100^{\circ} \mathrm{C}, 10 \mathrm{~min}\right)+(-) \mathrm{EC}$ & 0 \\
\hline 9 & Phe $+\beta$-Naphthoquinone & 8.2 \\
\hline 10 & Phe + Sodium $\beta$-naphthoquinone 4-sulfonate & 10.2 \\
\hline 11 & Phe + TLE $+\alpha$-Ketoglutaric acid +Pyridoxal phosphate & 0 \\
\hline 12 & Phe + TLE + Pyridoxal phosphate $+\mathrm{Mn}^{2+}+p$-Cresol & $\begin{array}{c}0 \\
\text { (Benzaldehyde } \begin{array}{l}\text { ca. } 30.8 \\
\times 10^{-2} \mu \text { mole) }\end{array}\end{array}$ \\
\hline
\end{tabular}

Reaction systems $1 \sim 10: 6 \mathrm{ml}$ total volume (M/15 phosphate buffer, $\mathrm{pH} 7.0), 25^{\circ} \mathrm{C}, 2 \mathrm{hr}$. Phe; 300 umoles, TLE; $1 \mathrm{ml}$ of tea leaves extract, (-)EC; $3 \mu$ moles (-)-epicatechin, $\mathrm{H}_{2} \mathrm{O}_{2}$ or $\mathrm{Mn}^{2+} ; 0.3 \mu$ mole, HRP; $30 \mu \mathrm{g}$ of horseradish peroxidase, quinones; $3 \mu$ moles.

Reaction systems $11^{6}$ : $9 \mathrm{ml}$ total volume (M/15 Tris-HCl buffer, $\mathrm{pH} 8.5$ ), $37^{\circ} \mathrm{C}, 3 \mathrm{hr}$. Phe; $90 \mu$ moles, TLE; $1 \mathrm{ml}, \alpha$-Ketoglutaric acid; $45 \mu$ moles, Pyridaxal phosphate; $3 \mu$ moles.

Reaction system 12: $9 \mathrm{ml}$ total volume (M/15 phosphate buffer, $\mathrm{pH} 7.0), 25^{\circ} \mathrm{C}, 2 \mathrm{hr}$. Phe; $90 \mu$ moles, TLE; $1 \mathrm{ml}$, Pyridoxal phosphate; $30 \mu$ moles, $\mathrm{Mn}^{2+} ; 0.3 \mu$ mole, $p$-Cresol; $0.09 \mu$ mole.

in higher yield as reported by J. M. Hill and P. J. G. Mann. ${ }^{\prime \prime}$

Carbonyl compounds produced from various amino acids by tea leaves extract

Examinations using various amino acids were attempted in the reaction system, containing amino acid, tea leaves extract and (-)-epicatechin. These results were summerized in Table II. It was revealed that glycine, alanine, valine, leucine, isoleucine, methionine and phenylalanine produced the corresponding aldehydes; formaldehyde, acetaldehyde, isobutyraldehyde, isovaleraldehyde, 2-methylbutanal, methional and phenylacetaldehyde, respectively. Glutamic acid, tyrosine and tryptophan were also presumed to produce the

7) J.M. Hill and P.J. G. Mann, Biochem. J., 99, 454 (1966). corresponding carbonyl compounds, however the products were not determined in this study. Although it was presumed that the value of determined carbonyl contents did not always represent the contents of the corresponding carbonyl compounds derived from the amino acid, methionine, isoleucine, valine and leucine might produced larger amounts of carbonyl compounds in the investigated amino acids.

\section{Effect of various phenols on the producibility of phenylacetaldehyde}

Table III showed that mono-phenols were no effective on the production of phenylacetaldehyde and that tri-phenols were a little and that di-phenols were most effective, especially (-)-epicatechin. In the reaction mixture of (-)-epicatechin and (-)-epigallocatechin gallate, which was one of the formation systems 
Table II. Carbonyl Compounds Produced from Various Amino ACids by Tea Leaves Extract

\begin{tabular}{|c|c|c|c|c|}
\hline \multirow{2}{*}{ Amino acid } & \multicolumn{3}{|c|}{ Main carbonyl compound 2,4-DNPH } & \multirow{2}{*}{$\begin{array}{l}\text { Produced total } \\
\text { carbonyl content } \\
\left(\mathrm{N} / 100 \mathrm{I}_{2} \mathrm{ml}\right)\end{array}$} \\
\hline & $R f(\mathrm{TLC})^{a)}$ & $\mathrm{mp}{ }^{\circ} \mathrm{C}$ & Identification & \\
\hline Gly & 0.50 & 163 & Formaldehyde & 0.23 \\
\hline Ala & 0.54 & 167 & Acetaldehyde & 0.15 \\
\hline Val & 0.77 & 180 & Isobutyraldehyde & 0.45 \\
\hline Leu & 0.88 & 121 & Isovaleraldehyde & 0.33 \\
\hline Ileu & 0.87 & 126 & 2-Methylbutanal & 0.46 \\
\hline Met & 0.57 & 128 & Methional & 0.65 \\
\hline Phe & 0.69 & 119 & Phenylacetaldehyde & 0.25 \\
\hline Glu & - & & & 0.06 \\
\hline Tyr & - & & & 0.13 \\
\hline Try & - & & & 0.27 \\
\hline
\end{tabular}

Reaction mixture, of $9 \mathrm{ml}$ total volume (M/15 phosphate buffer, $\mathrm{pH} 7.0$ ), contained $500 \mu$ moles of amino acids, $3 \mu$ moles of $(-)$-epicatechin and $1 \mathrm{ml}$ of tea leaves extract.

a) Thin-layer chromatography with developing solvent of benzene-ligroin-ethylacetate $(6: 6: 1)$.

TABLe III. EFfect of Various Phenols on the Production of Phenylacetaldehyde

\begin{tabular}{lc}
\multicolumn{1}{c}{ Phenol } & $\begin{array}{c}\text { Phenylacetaldehyde } \\
\text { (relative quantity) }\end{array}$ \\
\hline$p$-Coumaric acid & 0 \\
$p$-Cresol & 0 \\
(+)-Catechin & 31 \\
Catechol & 57 \\
(-)-Epicatechin & 100 \\
(-)-Epigallocatechin & 10 \\
(-)-Epigallocatechin gallate & 10 \\
Pyrogallol & trace \\
(-)-Epicatechin $+(-)$-Epigallocatechin gallate & 17
\end{tabular}

Reaction mixture, of $6 \mathrm{ml}$ total volume (M/15 phosphate buffer, $\mathrm{pH} 7.0$ ), contained $300 \mu$ moles of phenylalanine, $1 \mathrm{ml}$ of tea leaves extract and $3 \mu$ moles of phenol; where mono-phenol was used, $0.3 \mu$ mole of $\mathrm{H}_{2} \mathrm{O}_{2}$ was added in above mixture. Reaction was carried out at $25^{\circ} \mathrm{C}$ for $2 \mathrm{hr}$.

of theaflavin ${ }^{8}$ (a reddish orange pigment in black tea infution), the production of phenylacetaldehyde was depressed. Therefore, it was revealed that $o$-di-phenols, especially (-)epicatechin, reacted as the effective co-factor on the production system of phenylacetaldehyde

8) Y. Takino and H. Imagawa, Agr. Biol. Chem., 28, 255 (1964). from phenylalanine and that the effectiveness of (-)-epicatechin was inhibited by the coexistence of tri-phenol.

\section{Effects of the concentrations of phenols and quinone on the phenylacetaldehyde production}

As shown in Table IV, the most suitable concentration of $(-)$-epicatechin for the phenyl- 
Table IV. Effects of the Concentrations of Phenols and QunNones on the Phenylacetaldehyde Production

\begin{tabular}{lccccc}
$\quad$ Concentration (M) & $5 \times 10^{-6}$ & $5 \times 10^{-5}$ & $5 \times 10^{-4}$ & $5 \times 10^{-3}$ & $5 \times 10^{--2}$ \\
Phenol or quinone & & & & & - \\
(-)Epicatechin & 0.3 & 5.7 & 8.1 & 2.1 & - \\
Catechol & trace & 0.7 & 4.6 & 19.2 & 15.0 \\
Sodium $\beta$-naphtoquinone 4-sulfonate & 0 & trace & 10.2 & 125.0 & 217.0 \\
\hline
\end{tabular}

The figures represent the produced phenylacetaldehyde $\left(\times 10^{-2} \mu\right.$ mole $)$.

Reaction mixture, of $6 \mathrm{ml}$ total volume (M/15 phosphate buffer, $\mathrm{pH} 7.0$ ), contained $300 \mu$ moles of phenylalanine, $1 \mathrm{ml}$ of tea leaves extract and phenols or quinone.

Reaction was carried out at $25^{\circ} \mathrm{C}$ for $2 \mathrm{hr}$.

acetaldehyde production in the tea leaves extract-phenol-phenylalanine system was $5 \times 10^{-4} \mathrm{M}$ and that of catechol, $5 \times 10^{-3} \mathrm{M}$. At higher concentration of di-phenols the phenylacetaldehyde production was depressed. The optimum concentration of tea polyphenols on the reaction of tea leaves polyphenol oxidase was about 3 to $5 \times 10^{-3} \mathrm{M}$. Therefore, the optimum concentration of (-)-epicatechin in the tea leaves extract-phenol-phenylalanine system was one tenth of that of $(-)$-epicatechin in polyphenol oxidase-polyphenol system. These results showed that the phenylacetaldehyde production system was accelerated by the low concentration of quinone drived from (-)epicatechin and that the high concentration of quinone reacted as inhibitor on the system. In the case of quinone-phenylalanine system the production was nearly proportional to the concentration of quinone under $5 \times 10^{-3} \mathrm{M}$.

Effect of concentration of enzyme on the phenylacetaldehyde production and (-)-epicatechin oxidation

The production of phenylacetaldehyde decreased by diluting tea leaves extract (Fig. 2). Moreover, it was found that the phenylacetaldehyde production proceeded for 3 or 4 $\mathrm{hr}$ though the formation of oxidized (-)epicatechin, which was determined by the absorption at $398 \mathrm{~m} \mu,{ }^{9 \prime}$ almost stopped whithin

9) M. Nakagawa and H. Torii, Agr. Biol. Chem., 29, 278 (1965).

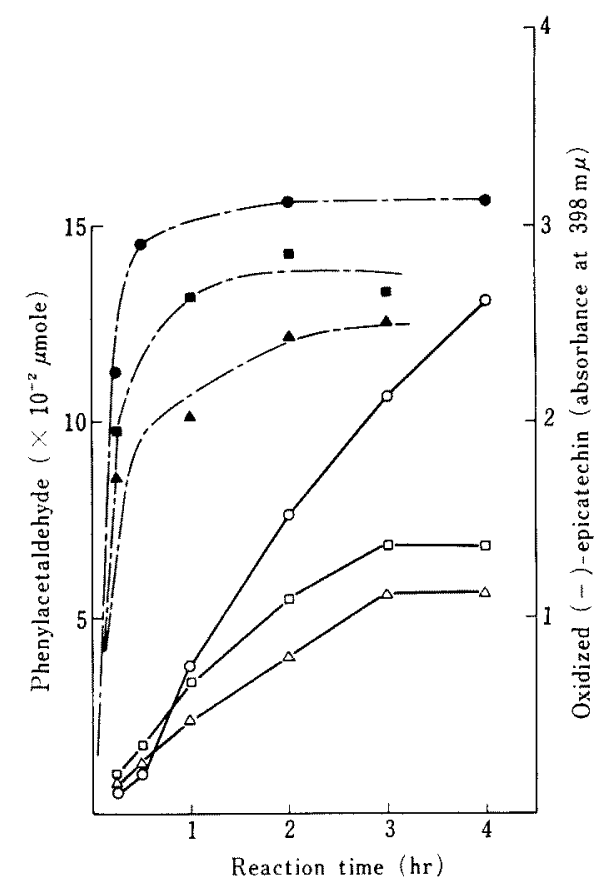

Fig. 2. Effect of Concentration of Enzyme on the Phenylacetaldehyde Production and (-)-Epicatechin Oxidation.

Reaction mixture, of $6 \mathrm{ml}$ total volume, contained $300 \mu$ moles Phe., $3 \mu$ mole (-)-epicatechin and tea leaves extract $(\mathrm{O}-\mathrm{O}$ and $-0 ; 1 \mathrm{ml}$, $\square-\square$ and $\square-\square ; \mathrm{I} / 2 \mathrm{ml}, \triangle-\Delta$ and $\mathbf{\Delta}-\Delta ; 1 / 4 \mathrm{ml}$ ). Real line; phenylacetaldehyde, broken line; oxidized (-)-epicatechin.

$1 \mathrm{hr}$ after the start of reaction. From the previous results, it was thought that the pro- 
duction of phenylacetaldehyde from phenylalanine was effected by oxidative enzyme in tea leaves extract. However, it was presumed that this reaction was not catalysed directly by enzymic system and might be stimulated by small amount of quinone which was produced in the reaction mixture by enzymic oxidation of di-phenols, and that the reaction continued until quinone produced was consumed by the reaction between quinone and amino acid.

Visible-light absorption spectra of the phenylacetaldehyde production system

As shown in Fig. 3, the tea leaves extract-

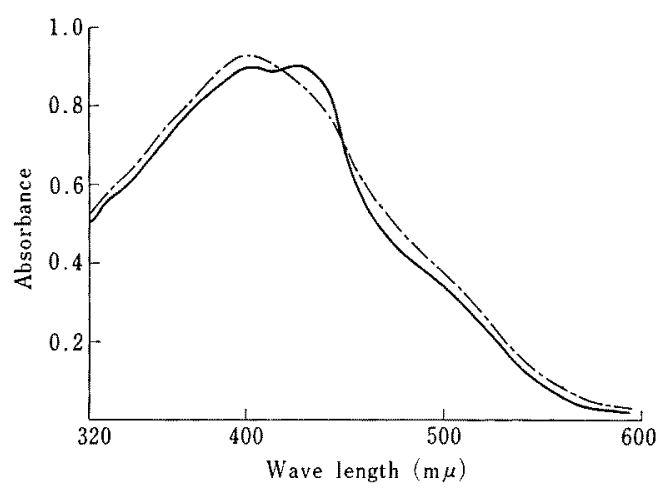

FIG. 3. Visible-light Absorption Spectra of Two Reaction Mixtures.

Real line; $300 \mu$ moles Phe $+3 \mu$ moles (-). epicatechin $+1 \mathrm{ml}$ tea leaves extract, $6 \mathrm{ml}$ total volume.

Broken line; 3 mmole (-)-epicatechin $+1 \mathrm{ml}$ tea leaves extract, $6 \mathrm{ml}$ total volume.

Measurement was done at one fourth concentration of original reaction mixture of $2 \mathrm{hr}$.

phenol-phenylalanine system gave the absorption maximum at $428 \mathrm{~m} \mu$ which was different from that of the polymerized substance formed by (-)-epicatechin alone.

\section{DISCUSSION}

The reaction that the aldehyde is produced from amino acid by tea leaves extract is regarded as Strecker degradation from the following reasons: 1) the ratio of radioactive phenylacetaldehyde to carbon dioxide produced from phenylalanine- $\mathrm{U}-{ }^{14} \mathrm{C}$ on the process of black tea fermentation is about $8: 1$; 2) in the tea leaves extract-(-)-epicatechinphenylalanine system it is supposed that the first step is the formation of o-quinone from (-)-epicatechin and then o-quinone reacts with phenylalanine; 3 ) in the same system the colored substance which is different from polymerized (-)-epicatechin is also formed.

In the tea leaves extract-phenol-amino acid system the effectiveness of (-)-epicatechin is inhibited by the coexistence of triphenol. This indicates that one of the $>\mathrm{CO}$ radicals of visinal tri-quinone reacts as the inhibitory factor. The optimum concentration of $(-)$ epicatechin on the tea leaves extract-phenolamino acid system was $5 \times 10^{-4} \mathrm{M}$, and the higher concentration of that inhibited the production of carbonyl compounds. This optimum concentration was about one tenth of that on the polyphenol oxidase-polyphenol system. In the system containing higher concentration of 0 -quinone derived from (-)epicatechin it is thought that most of $o$-quinone changes to polymerized product and the production of carbonyl compound is depressed, since the polymerization rate of o-quinone is much higher than the production rate of cabonyl compound from o-quinone and amino acid. Therefore, these two reaction may be competitive each other.

The production does not depend on the enzyme which is characteristic to aldehyde production, because the reaction system does not show the substrate specificity for amino acids (Table II). Therefore, it is considered concerning with the production of aldehyde from amino acid in black tea fermentation that the first step of the reaction is the formation of quinone from catechin by oxidative 
enzyme in tea leaves and then the quinone reacts with amino acid to produce carbonyl compound at the relatively low concentration of quinone.
Acknoweledgement. The authors wish to express their gratitude to Dr. I. Uritani, University of Nagoya, for his valuable suggestions. 